\title{
Impact of funding harm reduction programs for people who inject drugs in Mexico
}

\author{
Marisol Valenzuela-Lara, ${ }^{1}$ Marisol Ponce-Ramos, ${ }^{2}$ Karen Ruiz-Herrera, ${ }^{2}$ Agustín López-González ${ }^{3}$
}

Emory University, Atlanta GA, EE UU.

2 Dirección de Atención Integral Centro Nacional para la Prevención y el Control del VIH y el sida. Ciudad de México, México

${ }^{3}$ Dirección de Prevención y Participación Social, Centro Nacional para la Prevención y el Control del $\mathrm{VIH}$ y el sida, Ciudad de México, México

\section{Correspondence:}

Marisol Valenzuela-Lara

201 Dowman Dr,

Atlanta, GA 30322, EE. UU

Email: marisol.valenzuela.lara@emory. edu

Received: 15 March 2019

Accepted: 12 August 2019

Citation:

Valenzuela-Lara, M., Ponce-Ramos, M., Ruiz-Herrera, K., \& LópezGonzález, A. (2019). Impact of funding harm reduction programs for people who inject drugs in Mexico. Salud Mental, 42(4), 157-163.

DOI: $10.17711 /$ SM.0185-3325.2019.021

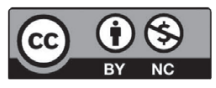

\begin{abstract}
Introduction. Despite evidence from harm reduction programs, there are limited data on their impact in Mexico. The Mexican National HIV Program has supported harm reduction programs implemented by community-based organizations both financially and technically. Objective. To obtain an estimate of HIV infections averted from 2015 to 2018 . Method. A deterministic model was developed to estimate the number of infections, with harm reduction projects financed by CENSIDA and implemented by Community-Based Organizations, using data reported from the period 2015 to 2018 . The benefit was obtained by estimating the costs of providing prevention programs and comparing the latter to the costs of providing care. Results. An analysis of 66,973 people included in harm reduction programs showed that an estimated 869 HIV infections were averted between 2015 and 2018. Potential savings obtained by providing these harm reduction services exceeded over $\$ 600,000$ Mexican pesos for every infection averted. Discussion and conclusion. Harm reduction services play a key role in reducing the incidence of HIV in Mexico. Ensuring their financing is necessary since, combined with other services, they are a cost-effective tool for reducing the economic and public health burden of HIVIAIDS.
\end{abstract}

Keywords: People who inject drugs, harm reduction, HIV.

\section{RESUMEN}

Introducción. A pesar de la evidencia que aportan los programas de reducción de daños, hay pocos datos sobre el impacto que tienen en México. El Programa Nacional de VIH en México ha apoyado técnica y financieramente la implementación de proyectos de reducción de daños operados por la sociedad civil. Objetivo. Estimar el número de infecciones de VIH evitadas en el periodo de 2015 a 2018. Método. Se desarrolló un modelo determinista para estimar el número de infecciones evitadas con los proyectos de reducción de daños financiados por CENSIDA e implementados por organizaciones de la sociedad civil a partir de los datos reportados durante el periodo 2015-2018. El beneficio se obtuvo al estimar el costo de proveer programas de prevención comparado con el costo de proveer tratamiento. Resultados. Del análisis de 66,973 personas contactadas con los programas, se estimaron 869 infecciones de VIH evitadas entre 2015 y 2018 . El ahorro potencial de proveer estos servicios de reducción de daños fue de más de $\$ 600$ mil pesos por infección evitada. Discusión y conclusión. Los servicios de reducción de daños cumplen un papel importante en la reducción de la incidencia de VIH en México. Asegurar su financiamiento es necesario ya que es una herramienta costo-efectiva si se le combina con otras estrategias para reducir la carga económica y de salud pública del VIH/sida.

Palabras clave: Personas que se inyectan drogas, reducción de daños, VIH. 


\section{INTRODUCTION}

The special session of the United Nations (UN) General Assembly in June 1998 was dedicated to the world drug problem. Nevertheless, today, three decades later, gaps remain in relation to the universal access of people who inject drugs PWIDs to HIV prevention, treatment, and care (United Nations Office on Drugs and Crime [UNODC], 2016).

Worldwide, there are an estimated 11.3 million PWIDs (United Nations Office on Drugs and Crime [UNODC], 2019), whereas in Mexico there are 109,079 (INPRFM \& CONADIC, 2017), whose distribution around of the country is mainly concentrated in the northern region, particularly in the cities of Tijuana and Ciudad Juárez. Estimates indicate that there are approximately 12,000 PWIDs in Tijuana, 10,000 in Ciudad Juárez (Centro Nacional para la Prevención y Control del VIH/SIDA [CENSIDA], 2010; Mathers et al., 2013), and 3,390 in Hermosillo (Ospina-Escobar, 2016). Nevertheless, more recent studies are needed to determine the number of people per region, not only in this population but also in other key populations affected by the epidemic. Likewise, since undertaking precise calculations is a complex task, United Nations Programme on HIV/AIDS (UNAIDS) and other agencies have developed standardized, consensual methods to make estimates between countries comparable (HIV Modeling Consortium, 2019).

Several studies conducted to characterize populations at risk of acquiring HIV have focused on the social environment and have pointed out its importance, since the spread of HIV is heavily influenced by social, economic, and political conditions, which have spurred interest in mapping the social, structural, and environmental factors shaping the risk of HIV acquisition (Rhodes, Singer, Bourgeois, Friedmand, \& Strathdee, 2005; Cruz et al., 2010).

Risk factors for HIV infection in PWIDs at the micro-environmental level include: a) physical risks such as places where drugs are injected, prisons and violence; $b$ ) social risks, such as social norms and peer pressure, social networks and the dynamics of relationships, sexuality and sexual orientation, local police practices, access to community health and welfare services, education, easy access to drugs, and peer education; d) economic risks, such as the cost of housing and health treatments, the cost of syringes and condoms, lack of income and employment, and survival through commercial sex; e) political risks, such as coverage of sterile syringes and needles, treatment coverage for substance use disorder (SUD), coverage of HIV detection and psychological counseling and antiretroviral therapy, programs regulating the distribution of material for injection, and access to social housing (Strathdee et al., 2010).

Factors within the macro environmental context include: a) physical ones such as drug trafficking and the distribution of routes, geographical changes in the pop- ulation, deportations, and distance from the epicenter of HIV; b) social ones such as gender inequalities, stigma and marginalization, wars, disasters, and racial or ethnic inequities; c) economic ones such as lack of spending on health services, growth of informal economies, transition of uncertain economy; d) political ones such as laws governing the access and exchange of syringes, laws regulating the treatment of SUDs, policies and laws governing universal coverage of antiretroviral treatment, public health policies regulating sex work, laws regulating the possession of substances of abuse and consumer paraphernalia, immigration policies and laws, and laws regulating the protection of human and health rights (Strathdee et al., 2010).

Several publications have demonstrated the importance of these factors, such as a 2009 study in New York City evaluating the prevalence of HIV infection, as well as risk behaviors in two groups of people who inject drugs: those ages 18 to 29 and those over 30. HIV prevalence was $9.0 \%$ and higher in the older $(9.5 \%)$ than the younger group (4.1\%) (Broz et al., 2014). This increase in incidence could be explained by the fact that in 2009, it was found that younger users in New York purchased sterile syringes in pharmacies $(60 \%)$ more frequently than those in the older group (39\%) (Broz et al., 2014).

A cohort study conducted in Vancouver evaluated the incidence of HIV in relation to substance use by injection over time. At five years, they found a cumulative incidence of HIV infection of $8.27 \%$. At 10 years of follow-up, cumulative incidence had increased to $10.04 \%$ and at 13 years of follow-up it was reported to be $11.88 \%$ (Montain et al., 2016).

In Mexico, the limited implementation of the reforms of decriminalization laws averted $2 \%(95 \%$ CI $[.2,3.0])$ of new HIV infections in people who inject drugs between 2012 and 2017 (Borquez et al., 2018).

In addition to sexual practices, people who inject drugs have a higher risk of acquiring sexually transmitted infections (STIs), as well as a greater chance of acquiring hepatitis $\mathrm{C}(\mathrm{HCV})$, which is six times more prevalent in those with HIV who inject drugs than in those who do not have HIV (Platt et al., 2016; Berbesi, Segura-Cardona, Montoya-Velez, \& Mateu-Gelabert, 2013).

Worldwide, women who inject drugs are more vulnerable to HIV infection than men, due to a greater tendency to engage in risky sexual behaviors, such as exchanging sex for money or drugs, having multiple sexual partners and sharing needles, as well as having unprotected sex with a partner who inject drugs (UNODC, 2019; Berbesi et al., 2013; Azim, Bontell, \& Strathdee, 2015). This is borne out on Mexico's northern border, where a higher prevalence of HIV has been observed in sex workers who inject drugs than in those who do not ( $12 \%$ versus $5 \%)$, mainly due to the fact that this is perpetuated by the user networks around them (Strathdee et al., 2008). 
In Latin America, it is estimated that the prevalence of HIV in people who inject drugs is 35 - 7\% (15.0 - 56.6) who together with Eastern Europe have the highest number of people who inject drugs living with HIV (Degenhardt et al., 2017).

In countries such as Honduras, Guatema, El Salvador, and Panama, HIV prelavence indicates a generalized epidemic, whereas Haiti has a similar prevalence to African countries (3.8\%) (Cruz et al., 2010).

In the case of Mexico, it is estimated that in 2015, the prevalence of HIV in people who inject drugs was $2.5 \%$, while several studies show that border states estimate a prevalence of $4.2 \%$ to $7.7 \%$ (Bautista-Arredondo, Colchero, Sosa-Rubí, Romero, \& Conde, 2012). More recent studies have found that the prevalence of HIV in drug use sites in Tijuana and Ciudad Juárez is 7.3\% and 3.2\% respectively (Fleiz-Bautista et al., 2019).

Both the geographical and the social situation of Mexico explain the vulnerability of the northern border. The dynamics of borders such as that of Mexico and other countries revolve around drug use, prostitution, and population mobility. These factors encourage the vulnerability of the population concentrated in these places (Strathdee, Magis-Rodriguez, Mays, Jimenez, \& Patterson, 2012).

Among Mexicans who report using abused substances, $5.1 \%$ have used an injectable drug at some time in their lives, with heroin remaining the substance of choice, with a $1.6 \%$ preference of use (DGE, 2016). It is estimated that each person who injects drugs uses an average of 7.2 syringes, $19 \%$ of which have been reused (Bucardo et al., 2005).

A key limitation in Mexico for the control of HIV in PWIDs is the lack of knowledge of serological status, where the low coverage of HIV monitoring and diagnosis programs and other STIs are a major problem for the epidemic. It is estimated that in both Tijuana and Ciudad Juárez, from 2004 to 2006 , only $46 \%$ of female sex workers and $30-38 \%$ of PWIDs were tested for HIV (Strathdee et al., 2012; Strathdee et al., 2013). A study conducted in 2005 in Tijuana and Ciudad Juárez proposed studying the barriers to HIV detection on the border between Mexico and the United States. It was found that a total of $3 \%$ of participants from both cities obtained reactive results in the HIV test (Strathdee et al., 2013).

Although this is a low figure, in both cities it was found that $65 \%$ of participants who had not been tested had missed at least one occasion to be tested. This situation is associated with the stigma surrounding injectable drug use, which also results in the "under-declaration" of drug use and inhibits the desire to undertake diagnostic tests. These elements constitute a risk factor for HIV/AIDS in Mexico (Bucardo et al., 2005).

The existence of public policies in Mexico continues to be strengthened with the aim of reducing STIs and HIV. The Harm Reduction Model, a strategy developed in the 1980s for PWIDs, is implemented as a means of finding the most effective way to reduce the damage caused by drug use through the provision of services that favor behavioral modification and health care (CENSIDA, 2008).

Between 2008 and 2010, a study was conducted to evaluate the combination of interventions to reduce risk factors for STIs and HIV among women engaged in sex work who inject drugs in the cities of Tijuana and Ciudad Juárez (Moyer et al., 2008). It included educational versus interactive sessions for the promotion of safe sex and the management of contaminated syringes in both cities. In Tijuana, sterile syringes were also supplied for the population studied. It was found that after 12 months of interventions, the incidence of HIV/STI, which was higher in Tijuana than Ciudad Juárez, fell by over $50 \%$ in both cities (Moyer et al., 2008). The acceptability and viability of harm reduction programs may be controversial in Mexico and should be further analyzed, in addition to including the provision of medical prescriptions for sterile syringes, the implementation of syringe vending machines and promoting safe injection sites, among others (Bucardo et al., 2005; Magis-Rodríguez, García-Sánchez \& Marín-Navarrete, 2018).

Harm reduction refers to policies, programs, and practices that primarily seek to reduce adverse health and social and economic consequences, resulting from the legal and illegal use of psychoactive drugs, without the need to reduce drug use. The International Harm Reduction Association (IHRA, 2010) seeks to reduce the damage associated with the use of psychoactive drugs in people who either cannot or do not wish to stop using them. Its defining characteristic is that it focuses on reducing harm rather than preventing drug use itself, and concentrates on those who continue using drugs (IHRA, 2010).

In keeping with the recommendations of the World Health Organization (WHO), the harm reduction package includes the following: opioid replacement therapy, HIV detection services, antiretroviral therapy, STI prevention and treatment, condom distribution programs for PWIDs and their partners, personalized information, education and communication, prevention, vaccination, diagnosis and treatment of viral hepatitis, prevention, diagnosis and treatment of tuberculosis, and community distribution of naloxone (World Health Organization, 2012).

Since 1994, CENSIDA has developed in Mexico various community-based and institutional strategies to bring harm reduction services to PWIDs in order to reduce HIV transmission. To this end, since 2014 the installed and technical-scientific capacity of the human resources of community organizations has been strengthened through funding for prevention and detection activities and those involving linkage to treatment (Magis-Rodríguez et al., 2018).

Although globally it has been proved that harm reduction is effective in preventing infections, very few studies in Mexico show the extent to which these interventions have impacted on averting new HIV infections. According to the 
epidemiological modeling study of the El Cuete IV cohort in Tijuana, it is estimated that harm reduction interventions such as the decriminalization of the personal use of certain drugs, together with the implementation of opioid substitution treatments, could prevent $21 \%$ of the new infections (Borquez et al., 2018). However, the impact of harm reduction interventions implemented by civil society organizations is as yet unknown, and constitutes the main focus of this study.

\section{METHOD}

\section{Study design}

A cross-sectional and epidemiological modeling study was conducted using data collected by the projects financed by CENSIDA during the 2014-2018 period to target the PWIDs population. Priority interventions of harm reduction projects included: a) safe delivery and/or exchange of needles and syringes, b) provision of prevention supplies, c) communication actions; and d) education on drug use and health care for HIV and STIs, quick tests for HIV, syphilis, and other STIs accompanied by counseling, linking reactive cases to health services in coordination with local authorities, support services, and other socio-cultural strategies.

\section{Participants}

Using the information reported on the population reached by the interventions, only the projects targeting people who inject drugs were used, of which a total of 66,973 people contacted was reported.

Funded harm reduction projects were implemented in cities in the northern region of Mexico: Tijuana, Mexicali, Ciudad Juárez, Chihuahua, Delicias, Agua Prieta, Caborca, Cajeme, Guaymas, Hermosillo, Navojoa, Nogales, and San Luis Río Colorado.

\section{Statistical analysis}

A descriptive analysis of the projects that met the inclusion criteria was undertaken. In order to estimate the number of new infections averted by CENSIDA-funded harm reduction programs, a deterministic model of HIV transmission derived from the use of non-sterile syringes in people who inject drugs was developed. For the purposes of this analysis, the risk of HIV transmission for every act of needle sharing is higher than the risk of transmission for each sexual act the former was assumed to be predominant. The susceptible population was estimated according to the number of people reached by the projects with a harm reduction component and estimates of HIV prevalence in key populations reported by CENSIDA.

Lastly, the model to determine the estimate of infections averted was drawn up on the basis of the MOT transmission models (Borquez et al., 2018; Case et al., 2012; Kessler et al., 2013), which resulted in the $I^{\prime}=n E(1-p) c \beta$ (1-i) model, whose parameter was obtained from various sources (Table 1).

\section{Ethical considerations}

This study is considered a risk-free investigation, in accordance with Article 17 of the General Law of Health in Research Matters for Health, since there are no activities that involving human beings, and only statistical data are used.

\section{RESULTS}

In 2015 and 2018, a total of 688 projects were identified that reported contacting $1,870,885$ people. Thirty-seven $(5.4 \%)$ of these projects included PWIDs yielding a total of 81,403 contacts through three screening projects $(n=4,552), 18$ projects to avert new infections $(n=9,878)$, and 16 harm reduction projects ( $n=66,973)$, the last of which is the intervention that reached the largest population. No harm reduction projects were funded in 2014.

The number of infections averted was estimated from the 66,973 people reached through harm reduction projects, resulting in 868 infections associated with the harm reduction actions financed by CENSIDA and implemented by civil society organizations.

Table 1

Model for estimating HIV infections averted in PID

\begin{tabular}{|c|c|c|c|}
\hline Parameter & Variable & Value & Source \\
\hline Population reached by harm reduction projects & $\mathrm{n}$ & 66,973 & (CENSIDA, 2017) \\
\hline Proportion of recent unsafe injections & $\mathrm{E}$ & $54.0 \%$ & (Degenhardt et al., 2017) \\
\hline HIV prevalence among PID & $\mathrm{p}$ & $5.8 \%$ & (CENSIDA, 2017) \\
\hline Number of unsafe injections a year & c & 25 & (Kessler et al., 2013) \\
\hline Probability of transmission by unsafe injections & $\beta$ & 0.003 & (Kessler et al., 2013) \\
\hline $\begin{array}{l}\text { Effect on HIV transmission associated with harm } \\
\text { reduction programs }\end{array}$ & $\mathrm{i}$ & 0.66 & (Aspinall, 2014) \\
\hline
\end{tabular}




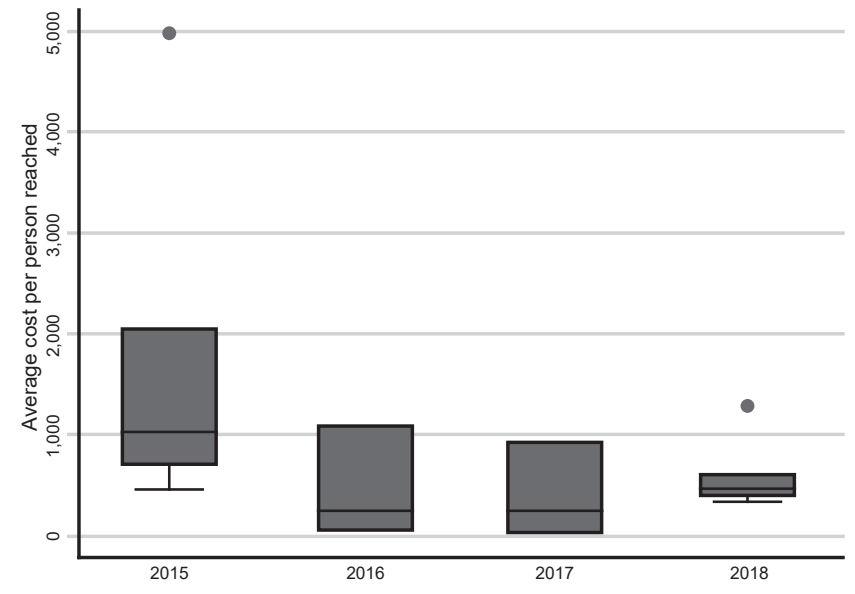

Figure 1. Average cost of people reached by harm reduction projects per year of project implementation.

Note: 2015: \$1,838.90 (max-min / \$426.58 - \$4.963.87); 2016: \$459.77 (max-min / \$33.66 - \$1,099.99); 2017: \$400.31 (max-min / \$34.75 - \$924.33); 2018: \$613.90 (max-min / $\$ 349.08-\$ 1,291.85$.

In total, $\$ 13,206,323.20$ pesos were invested in the 16 projects mentioned. The average cost per person reached during the period was $\$ 927.77$ (min: $\$ 33.66$, max: $\$ 4,963.87), 2017$ being the year with the lowest average cost (Figure 1).

\section{DISCUSSION AND CONCLUSION}

The model for this study estimated 869 (an average of 217 per year) HIV infections averted through the provision of harm reduction programs, targeting the population that injects drugs in 2015, 2016, 2017, and 2018, which underlines the importance of maintaining and expanding these programs. The total investment made by CENSIDA was $\$ 13,206,323.20$, equivalent to an average cost of $\$ 15,197$ pesos per infection averted, well below the annual cost of antiretroviral treatment for a person living with HIV in 2018 (\$31,344), with a 20-year survival rate. Accordingly, the $\$ 15,000$ pesos investment per averted infection would imply savings of over $\$ 600,000$ pesos.

Improving the health of PWIDs, including the reduction of HIV and hepatitis $\mathrm{C}$ transmission, remains an important task for health services, together with the expansion of the coverage of these services.

The results presented in this study are significantly smaller than those of studies from other countries, probably due to methodological variations such as sample size and the length of the analysis period. A study in Switzerland (Marzel et al., 2018) estimated an impact of 15,903 infections averted, with an average 454 infections per year between 1980 and 2015, whereas one in China (Ni, Fu, Chen, Hu, \& Wheeler et al., 2012) estimated 5,678 infections averted with an average of 1,135 per year from 2005 to 2010 .
However, there may be other explanations associated with the nature of the epidemic in each country. For example, a study in Canada (Nosyk et al., 2017) estimated 2,473 (2,279 - 2,855) infections averted through the implementation of harm reduction, with an average of 145 per year, from 1996 to 2013. Despite the fact that this was a longer period, the average number of infections averted per year was lower than that obtained in Mexico.

In addition to the methodological variations, other factors that could be influencing these differences are the interventions included in harm reduction programs, since the package of harm reduction services in Switzerland included some that are as yet unavailable in Mexico: syringe vending machines and supervised injection sites. At the same time, in Nosyk's estimate (2017), modeling was done on the basis of different scenarios, including the joint impact of harm reduction combined with antiretroviral treatment. In this respect, future studies in Mexico could consider doing modeling that takes both into account.

Limitations of this study include the fact that the data may not be representative of the entire population at risk in Mexico, since, according to the 2016-2017 ENCODAT survey, it is estimated that there are approximately 109,079 people in Mexico who inject drugs, of whom a total of $76,140(69 \%)$ would have been reached in the period from 2015 to 2018 . However, this may be an overestimate, since some of the same people may have been reached in certain years.

Another limitation is the lack of a direct association between the reduction of infections and a specific intervention, since the analysis is conducted with the population reached through harm reduction interventions as a whole. A broader study is required to determine the impact of harm reduction through other civil society actions implemented without the financial support of CENSIDA, which have another source of funding, in addition to other harm reduction services either financed or implemented by other institutions in the health sector. These include the methadone treatment service provided, for example, by private clinics and Centros de Integración Juvenil, A.C. given that, these services are not included in the modeling since the funded projects did not include opioid replacement therapy as a component.

According to the study on coverage of harm reduction interventions (IHRA) (Stone \& Shirley-Beavan, 2018), in Mexico, an average of eight (6-12) syringes are distributed per person who injects drugs. Fifteen out of every 100 PWIDs receive treatment for opioid replacement and only three out of 100 take an HIV test. These figures represent an area of opportunity due to the low level of application of the latter. It is therefore necessary to expand harm reduction services to people who use drugs, to increase coverage and therefore increase the number of infections averted. This will only be possible if a financing mechanism is 
guaranteed. Since worldwide financing for harm reduction programs is currently in crisis, it is necessary to invest in cost-effective interventions in order to optimize resources in the response to the HIV epidemic (Cook, Bridge, McLean, Phelan, \& Barrett, 2014).

\section{Funding}

None.

\section{Conflict of interest}

The authors declare a direct current or previous direct contractual relationship with CENSIDA in coordination and managerial positions. However, the analyses and opinions in this paper are the sole responsibility of the authors and do not represent the official position of the institution.

\section{REFERENCES}

Aspinall, E. J., Nambiar, D., Goldberg, D. J., Hickman, M., Weir, A., Van Velzen, E., ... Hutchinson, S. J. (2014). Are needle and syringe programmes associated with a reduction in HIV transmission among people who inject drugs: a systematic review and meta-analysis. International Journal of Epidemiology, 43(1), 235248. doi: 10.1093/ije/dyt243

Azim, T., Bontell, I., \& Strathdee, S. A. (2015). Women, drugs and HIV. International Journal of Drug Policy, 26(Suppl 1), S16-S21. doi: 10.1016/j. drugpo.2014.09.003

Bautista-Arredondo, S., Colchero, M. A., Sosa-Rubí, S. G., Romero, M., \& Conde, C. (2012). Diagnóstico situacional, mapeo de sitios de encuentro y evaluación de impacto de las estrategias de prevención en México. Informe sobre la encuesta en sitios de encuentro de HSH. Cuernavaca, Morelos: Secretaría de Salud. Instituto Nacional de Salud Pública (INSP).

Berbesi, D., Segura-Cardona, A., Montoya-Vélez, L., \& Mateu-Gelabert, P. (2013). Consumo de heroína inyectada en Colombia y comportamientos de riesgo. Salud mental, 36(1), 27-31.

Borquez, A., Beletsky, L., Nosyk, B., Strathdee, S. A., Madrazo, A., Abramovitz, D., ... Martin, N. K. (2018). The effect of public health-oriented drug law reform on HIV incidence in people who inject drugs in Tijuana, Mexico: an epidemic modelling study. The Lancet Public Health, 3(9), e429-e437. doi: 10.1016/ S2468-2667(18)30097-5

Broz, D., Pham, H., Spiller, M., Wejnert, C., Le, B., Neaigus, A., \& Paz-Bailey, G. (2014). Prevalence of HIV infection and risk behaviors among younger and older injecting drug users in the United States, 2009. AIDS and Behavior, 18(Suppl 3), 284-296. doi: 10.1007/s10461-013-0660-4

Bucardo, J., Brouwer, K. C., Magis-Rodríguez, C., Ramos, R., Fraga, M., Perez, S. G., ... Strathdee, S. A. (2005). Historical trends in the production and consumption of illicit drugs in Mexico: implications for the prevention of blood borne infections. Drug and Alcohol Dependence, 79(3), 281-293. doi: 10.1016 / j.drugalcdep.2005.02.003

Case, K. K., Ghys, P. D., Gouws, E., Eaton, J. W., Borquez, A., Stover, J., ... Hallett, T. B. (2012). Understanding the modes of transmission model of new HIV infection and its use in prevention planning. Bulletin of the World Health Organization, 90(11), 831-838A. doi: 10.2471/BLT.12.102574

Centro Nacional para la Prevención y Control del VIH/SIDA [CENSIDA]. (2008). Manual para la prevención del VIH/SIDA en usuarios de drogas inyectadas. México: Secretaría de Salud, ISBN 970-721-139-3. Retrieved from: http://www. censida.salud.gob.mx/descargas/biblioteca/documentos/manual_udi2008.pdf

Centro Nacional para la Prevención y Control del VIH/SIDA [CENSIDA]. (2010). Estimaciones de volumen de población HSH y UDI. Documento de trabajo. Centro Nacional para la Prevención y Control del SIDA. Dirección de Investigación Operativa. Ciudad de México.

Centro Nacional para la Prevención y Control del VIH/SIDA [CENSIDA]. (2017). Reporte anual de la aplicación de pruebas para la detección del VIH en la
Secretaría de Salud, 2016. Boletín de Atención Integral de Personas con VIH, 3(1), 7-19 Retrieved from: https://www.gob.mx/cms/uploads/attachment/ file/226743/Boletin_Nal_CENSIDA_AT_IN_ene_mar_2017.pdf

Cook, C., Bridge, J., McLean, S., Phelan, M., \& Barrett, D. (2014). The funding crisis for harm reduction: Donor retreat, government neglect and the way forward. London: International Harm Reduction Association. ISBN 978-0-9927609-1-5. Retrived from: https://www.hri.global/files/2014/09/22/Funding_report_2014. pdf

Cruz Juárez, A., Coronel Martín del Campo, G., Pavón-León, P., GogeascoecheaTrejo, M., De San Jorge Cárdenas, X., Blázquez-Morales, M., ... Ramírez Cruz, C. (2010). Consumo de drogas y VIH/SIDA en Centroamérica: una revisión de los modelos y teorías. Revista Médica de la Universidad Veracruzana, 10(2), 24-31. Retrived from: https://www.medigraphic.com > pdfs > veracruzana > muv-2010 > muv102d

Degenhardt, L., Peacock, A., Colledge, S., Leung, J., Grebely, J., Vickerman, P., ... Mattick, R. (2017). Global prevalence of injecting drug use and sociodemographic characteristics and prevalence of HIV, HBV, and $\mathrm{HCV}$ in people who inject drugs: a multistage systematic review. The Lancet Global Health, 5(12), e1192-e1207. doi: 10.1016/S2214-109X(17)30375-3

Dirección General de Epidemiología. (2016). Informe SISVEA. Sistema de Vigilancia Epidemiológica para las Adicciones. Secretaría de Salud. Retrieved from: http://187.191.75.115/gobmx/salud/documentos/info_sisvea/informes_ sisvea 2016.pdf

Fleiz-Bautista, C., Domínguez-García, M., Villatoro-Velázquez, J. A., VázquezQuiroz, F., Zafra-Mora, E., Sánchez-Ramos, R., ... Medina-Mora M. E. (2019). Cuqueando la Chiva: Contextos del consumo de heroina en la frontera norte de México. Ciudad de México, México: Instituto Nacional de Psiquiatría Ramón de la Fuente Muñiz.

HIV Modelling Consortium. (2019). HIV Modelling Consortium: Summary of aims, objectives, and work packages. Retrieved from: http://www.hivmodelling.org/ sites/default/files/HIV\%20MC\%20Core\%20Slide\%20Deck_2015.pdf

Instituto Nacional de Psiquiatría Ramón de la Fuente Muñiz, Instituto Nacional de Salud Pública [INPRFM], Comisión Nacional Contra las Adicciones [CONADIC]. (2017) Encuesta Nacional de Consumo de Drogas, Alcohol y Tabaco 2016-2017: Reporte de Drogas. Ciudad de México, México: Secretaría de Salud.

International Harm Reduction Association (2010). What is Harm Reduction? A position statement from the International Harm Reduction Association. IHRA Briefing. Recuperado de: https://www.hri.global/files/2010/08/10/Briefing What_is_HR_English.pdf

Kessler, J., Myers, J. E., Nucifora, K. A., Mensah, N., Kowalski, A., Sweeney, M., ... \& Braithwaite, R. S. (2013). Averting HIV infections in New York City: A modeling approach estimating the future impact of additional behavioral and biomedical HIV prevention strategies. PloS One, 8(9), e73269. doi: 10.1371/ journal.pone.0073269

Magis-Rodríguez, C., García-Sánchez, J. A., \& Marín-Navarrete, R. (2018). Harm reduction among people who inject drugs in Mexico. Salud Mental, 41(4), 153156. doi: $10.17711 /$ SM.0185-3325.2018.023

Marzel, A., Kusejko, K., Weber, R., Bruggmann, P., Rauch, A., Roth, J. A., ... \& Swiss HIV Cohort Study (2018). The cumulative impact of harm reduction on the Swiss HIV epidemic: Cohort study, mathematical model, and phylogenetic analysis. Open Forum Infectious Diseases, 5(5), ofy078. doi: 10.1093/ofid/ofy078

Mathers, B. M., Degenhardt, L., Bucello, C., Lemon, J., Wiessing, L., \& Hickman, M. (2013). Mortality among people who inject drugs: A systematic review and meta-analysis. Bulletin of the World Health Organization, 91(2), 102-123. doi: 10.2471/BLT.12.108282

Montain, J., Ti, L., Hayashi, K., Nguyen, P., Wood, E., \& Kerr, T. (2016). Impact of length of injecting career on HIV incidence among people who inject drugs. Addictive Behaviors, 58, 90-94. doi: 10.1016/j.addbeh.2016.02.020

Moyer, L. B., Brouwer, K. C., Brodine, S. K., Ramos, R., Lozada, R., Firestone Cruz, M., ... Strathdee, S. A. (2008). Barriers and missed opportunities to HIV testing among injection drug users in two Mexico-US border cities. Drug and Alcohol Review, 27(1), 39-45. doi: 10.1080/09595230701710845

Ni, M. J., Fu, L. P., Chen, X. L., Hu, X. Y., \& Wheeler, K. (2012). Net financial benefits of averting HIV infections among people who inject drugs in Urumqi, 
Xinjiang, Peoples Republic of China (2005-2010). BMC Public Health, 12(1), 572. doi: 10.1186/1471-2458-12-572

Nosyk, B., Zang, X., Min, J. E., Krebs, E., Lima, V. D., Milloy, M. J., ... Montaner, J. (2017). Relative effects of antiretroviral therapy and harm reduction initiatives on HIV incidence in British Columbia, Canada, 1996-2013: A modelling study. The Lancet HIV, 4(7), e303-e310. doi: 10.1016/S2352-3018(17)30045-0

Ospina-Escobar, A. (2016). Personas que se inyectan drogas en Hermosillo, Sonora. Metodología para su registro. Región y sociedad, 28(67), 45-77.

Platt, L., Easterbrook, P., Gower, E., McDonald, B., Sabin, K., McGowan, C., ... Vickerman, P. (2016). Prevalence and burden of HCV co-infection in people living with HIV: A global systematic review and meta-analysis. The Lancet Infectious Diseases, 16(7), 797-808. doi: 10.1016/S1473-3099(15)00485-5

Rhodes, T., Singer, M., Bourgois, P., Friedmand, S. R., \& Strathdee, S. A. (2005). The social structural production of HIV risk among injecting drug users. Social Science \& Medicine, 61(5), 1026-1044. doi: 10.1016/j.socscimed.2004.12.024

Stone, K. \& Shirley-Beavan, S. (2018). The Global State of Harm Reduction 2018. London: Harm Reduction International. ISBN: 978-0-9935434-7-0. Retrieved from: https://www.hri.global/files/2019/02/05/global-state-harmreduction-2018.pdf

Strathdee, S. A., Philbin, M. M., Semple, S. J., Pu, M., Orozovich, P., Martinez, G., ... Patterson, T. L. (2008). Correlates of injection drug use among female sex workers in two Mexico-U.S. border cities. Drug and Alcohol Dependence, 92(1-3), 132-140. doi: 10.1016/j.drugalcdep.2007.07.001

Strathdee, S. A., Hallett, T. B., Bobrova, N., Rhodes, T., Booth, R., Abdool, R., \& Hankins, C. A. (2010). HIV and risk environment for injecting drug users: the past, present, and future. The Lancet, 376(9737), 268-284. doi: 10.1016/S01406736(10)60743-X
Strathdee, S. A., Magis-Rodriguez, C. L., Mays, V. M., Jimenez, R., \& Patterson, T. L. (2012). The emerging HIV epidemic on the Mexico-U.S. border: An international case study characterizing the role of epidemiology in surveillance and response. Annals of Epidemiology, 22(6), 426-438. doi: 10.1016/j. annepidem.2012.04.002

Strathdee, S. A., Abramovitz, D., Lozada, R., Martinez, G., Rangel, M. G., Vera, A., ... Patterson, T. L. (2013). Reductions in HIV/STI incidence and sharing of injection equipment among female sex workers who inject drugs: results from a randomized controlled trial. PloS One, 8(6), e65812. doi: 10.1371/journal. pone. 0065812

United Nations Office on Drugs and Crime [UNODC]. (2016). Documento final del periodo extraordinario de sesiones de la Asamblea General de las Naciones Unidas sobre el problema mundial de las drogas celebrado en 2016. Nueva York: Naciones Unidas. Retrieved from: https://www.unodc.org/documents/ postungass2016/outcome/V1603304-S.pdf

United Nations Office on Drugs and Crime [UNODC]. (2019). World Drug Report 2019. Vienna, Austria: United Nations Publication. ISBN: 978-92-1-1483147. Retrieved from: https://wdr.unodc.org/wdr2019/prelaunch/WDR19 Booklet_1_EXECUTIVE_SUMMARY.pdf

World Health Organization. (2012). WHO, UNODC, UNAIDS technical guide for countries to set targets for universal access to HIV prevention, treatment and care for injecting drug users - 2012 revision. Geneva, Switzerland: WHO Document Production Services. ISBN: 978-92-4-159776-0. Retrieved from: https://www.who.int/hiv/pub/idu/targets_universal_access/en/ 